\title{
Article
}

\section{Effect of Ni doping on the catalytic properties of nanostructured peony-like $\mathrm{CeO}_{2}$}

\author{
XIAN Cunni a, WANG Shaofei a, SUN Chunwen a, LI Hong a,*, CHAN Suiwai ${ }^{b}$, CHEN Liquan a \\ a Key Laboratory for Renewable Energy, Institute of Physics, Chinese Academy of Sciences, Beijing 100190, China \\ b Department of Applied Physics and Applied Mathematics, Columbia University, New York, USA
}

\section{A R T I C L E I N F O}

\section{Article history:}

Received 13 August 2012

Accepted 12 October 2012

Published 20 February 2013

\section{Keywords:}

Nanostructured ceria

Nickel

Carbon monoxide

Oxidation

Methane

Partial oxidation

\begin{abstract}
A B S T R A C T
Nanostructured ceria materials have attracted wide attention as catalysts, and the doping of these materials with rare earth elements to modify their catalytic activity has been comprehensively investigated. A novel type of Ni-doped hierarchical nanostructured peony-like ceria (PCO) has been prepared and its catalytic activity is investigated and compared with that of Ni-loaded samples. The prepared Ni-doped ceria have nanoscale grain sizes and open mesopores. This unique morphology endows it with superior catalytic activity for the oxidation of $\mathrm{CO}$ and the partial oxidation of methane. It is found that extra oxygen vacancies are generated in the ceria, and the reducibility of the ceria is highly enhanced after Ni-doping. The catalytic activity for $\mathrm{CO}$ oxidation is improved after $\mathrm{Ni}$-doping, compared with that of pure ceria and Ni-loaded ceria. In the reaction for the partial oxidation of methane, the 3.8 atm\% Ni-loaded PCO sample realizes a higher $\mathrm{CH}_{4}$ conversion than the $\mathrm{Ni}$-doped ceria. However, it is found that the onset temperature for $\mathrm{CH}_{4}$ conversion decreases from $400{ }^{\circ} \mathrm{C}$ for the pure PCO and $3.8 \mathrm{~atm} \%$ Ni-loaded PCO sample, to $340{ }^{\circ} \mathrm{C}$ for the $5.7 \mathrm{~atm} \%$ Ni-doped PCO sample.
\end{abstract}

(C) 2013, Dalian Institute of Chemical Physics, Chinese Academy of Sciences. Published by Elsevier B.V. All rights reserved.

\section{Introduction}

$\mathrm{CeO}_{2}$-based materials have attracted much attention in recent years, due to their high catalytic activity for CO oxidation [1-3], water-gas shift reactions [4-6], reformation of hydrocarbons $[7,8]$, and three-way catalysis for the elimination of toxic auto-exhaust [6,9]. The excellent catalytic activity of $\mathrm{CeO}_{2}$-based materials is related to the redox reaction of $\mathrm{Ce}^{\mathrm{III}} / \mathrm{Ce}^{\mathrm{IV}}$ and the presence of intrinsic oxygen vacancies $[10,11]$. The catalytic activity can be significantly enhanced by changing the morphology of the catalysts $[12,13]$. Recently, hierarchical nanostructured ceria materials have been prepared using a hydrothermal method in our group [14,15]. They have a similar morphology to the Chinese peony, so we named these materials as peony-like $\mathrm{CeO}_{2}$ (PCO). The PCO-based materials have an open mesoporous microstructure. The thickness of the petals is in the range of $20-50 \mathrm{~nm}$, and the grain size is approximately 6-8 $\mathrm{nm}$. Their surface area is above $100 \mathrm{~m}^{2} / \mathrm{g}$. Compared with commercial ceria, they show higher thermal stability [16] and much higher activity for CO oxidation [14,15], ethanol reformation [17], and as active supporters in the anode active layer and cathode layer in solid oxide fuel cells (SOFCs) $[18,19]$.

The catalytic activity of $\mathrm{CeO}_{2}$ can also be modified significantly by metal loading. It has been found that $\mathrm{CeO}_{2}$ interacts with the loaded metal, and the interfacial interaction gives the composite oxide unusual features compared with pure ceria [20]. One of the most studied catalysts is Ni supported by

\footnotetext{
* Corresponding author. Tel.: +86-10-82648067; Fax: +86-10-82649046; E-mail: hli@iphy.ac.cn This work was supported by the National Natural Science Foundation of China (511172275) and the National Basic Research Program of China (973 Program, 2012CB215402).

DOI: 10.1016/S1872-2067(11)60466-X | http://www.sciencedirect.com/science/journal/18722067 | Chin. J. Catal., Vol. 34, No. 2, February 2013
} 
$\mathrm{CeO}_{2}$-based materials; this catalyst is effective in exploiting the synergetic effects of $\mathrm{Ni}$ and $\mathrm{CeO}_{2}$. Nickel shows high activity for the reformation of hydrocarbons, similar to precious metals, but with a much lower cost $[21,22]$. Nickel is also used as a catalyst for carbon nanotube growth because of its high catalytic activity for the cleavage of the $\mathrm{C}-\mathrm{C}$ bond in hydrocarbons [23-25]. This also gives rise to the deactivation of the Ni-based catalyst in the reformation of the hydrocarbons, due to the formation of carbon. Fortunately, the coking problem can be alleviated by modifying the properties of the support [24,2628]. As an oxygen ion conductor, $\mathrm{CeO}_{2}$ has been demonstrated to be effective in impeding the formation of carbon; it achieves this by transporting oxygen vacancies from the bulk to the surface, to promote the oxidation of carbon species [10,11]. Accordingly, Ni-loaded $\mathrm{CeO}_{2}$ catalysts are widely used in water-gas shift reactions $[4,29]$, the partial oxidation of methane (POM) [30-32], and the reformation of ethanol [17,33]. The most important component in this composite catalyst is believed to be the metallic $\mathrm{Ni}$, while the ceria support also plays a noticeable role. It has been confirmed that catalysts with $\mathrm{CeO}_{2}$ support have higher activity and lower deactivation rates than those with inert supports, such as $\mathrm{Al}_{2} \mathrm{O}_{3}$ or $\mathrm{SiO}_{2}$ [34-36]. The former benefits from the superior oxygen storage capacity and transport activity in the ceria.

The catalytic activity of ceria can be also modified by doping with Ga, La, Zr, Sn, Pr, or $\mathrm{Cu}[10,12,37]$. The $\mathrm{Cu}$-doped ceria material shows unusual structural and chemical properties that favor the formation of oxygen vacancies, and can be reversibly reduced [37]. Taking this approach further, we expect that $\mathrm{Ni}$-doped ceria materials would show some novel properties. However, it is difficult to dope $\mathrm{Ni}$ into the $\mathrm{CeO}_{2}$ lattice with a large molar ratio, due to the large discrepancy in ionic radius between $\mathrm{Ce}$ and $\mathrm{Ni}$. This could be one of the reasons for the relative lack of reports in the literature on Ni-doped ceria. Thurber et al. [38] studied the ferromagnetism of Ni doped into $\mathrm{CeO}_{2}$. It was claimed that the $\mathrm{CeO}_{2}$ retained its cubic fluorite structure even when the $\mathrm{Ni}$ doping concentration reached as high as $10 \mathrm{~atm} \%$ of the nominal composition, and that the doping could decrease the grain size and generate additional strain in the lattice. Jalowiecki-Duhamel et al. [39] found that $\mathrm{CeNi}_{x} \mathrm{O}_{y}$ mixed oxides are large catalytic hydrogen reservoirs with marked diffusion properties for hydrogen species. Yisup et al. [40] reported that Ce-Ni-O mixed oxides were highly active for the catalytic oxidation of methane. Kaneko et al. [41] claimed that the reactivity in a two-step water-splitting reaction for solar $\mathrm{H}_{2}$ production was improved by $\mathrm{Ni}$-doping in ceria. However, none of these studies clarified this basic fact for $\mathrm{Ni}$-doped ceria; did the nickel really enter the lattice of the ceria?

The activities of Ni-loaded and Ni-doped ceria catalysts have been extensively studied [17,21,22,39-41], but the difference in the catalytic activity between them is rarely reported. In this work, Ni-doped peony-like ceria catalysts were successfully prepared, and the effects of $\mathrm{Ni}$ doping on the structure and catalytic activity of $\mathrm{CeO}_{2}$ were studied. For comparison, Ni-loaded PCO samples were also prepared at the same time. The catalytic activities for $\mathrm{CO}$ oxidation and POM reactions were also investigated.

\section{Experimental}

\subsection{Catalyst preparation}

\subsubsection{Synthesis of Ni-doped peony-like ceria}

All of the doped peony-like ceria materials were synthesized using the hydrothermal method described in our previous report [14]. In brief, hydrate cerium (III) nitrate (AR, 99\%), hydrate nickel nitrate (AR, $\geq 98 \%$ ), glucose, acrylamide, and ammonia aqueous solutions were purchased from Beijing Chemical Reagents Company. The hexahydrated nickel nitrate was dissolved in de-ionized water to obtain a solution with a $\mathrm{Ni}^{2+}$ concentration of $0.2 \mathrm{~mol} / \mathrm{L}$. Then, hydrate cerium nitrate, the $\mathrm{Ni}^{2+}$ solution (the total cation concentration was $0.005 \mathrm{~mol}$, with molar ratios of dopant cation $\mathrm{Ni}^{2+}$ to $\mathrm{Ce}^{3+}$ of $0.05: 0.95$, 0.1:0.9, 0.15:0.85, and 0.2:0.8), $0.01 \mathrm{~mol}$ glucose, $0.015 \mathrm{~mol}$ acrylamide, and $80 \mathrm{ml}$ of de-ionized water were mixed in a Teflon autoclave with a capacity of $100 \mathrm{ml}$. The $\mathrm{pH}$ value of the solution was then adjusted to approximately 10 via dropwise addition of an aqueous ammonia solution. After continuous stirring at room temperature for $3 \mathrm{~h}$, the autoclave was sealed and kept in an oven at $180{ }^{\circ} \mathrm{C}$ for $24 \mathrm{~h}$. The precipitate was collected from the autoclave after the suspension was cooled to room temperature. After being washed with de-ionized water and alcohol and dried at $80{ }^{\circ} \mathrm{C}$, the Ni-doped peony-like ceria materials were obtained via calcining, using a previously reported two-step procedure [14].

\subsubsection{Synthesis of Ni-loaded peony-like ceria}

The peony-like $\mathrm{CeO}_{2}$ materials were synthesized using the same process as that described in a previous paper [14]. The Ni-loading was achieved using the nitrate impregnation method. Peony-like $\mathrm{CeO}_{2}(0.5 \mathrm{~g})$ was added to $40 \mathrm{ml}$ of de-ionized water, and after stirring at room temperature for $3 \mathrm{~h}, 855 \mu \mathrm{l}$ ( $5.7 \mathrm{~atm} \% \mathrm{Ni}$ content) of a $0.2 \mathrm{~mol} / \mathrm{L} \mathrm{Ni}^{2+}$ solution was added; 8 $\mathrm{h}$ of additional, vigorous stirring was performed, and the sample was dried at $80{ }^{\circ} \mathrm{C}$. The Ni-loaded material was obtained after the sample was dried at $110^{\circ} \mathrm{C}$ for $2 \mathrm{~h}$ and calcined at 450 ${ }^{\circ} \mathrm{C}$ for $4 \mathrm{~h}$ in air.

\subsection{Characterization}

X-ray diffraction (XRD) measurements were carried out using a Holland X'Pert Pro MPD X-ray diffractometer equipped with a monochromatized $\mathrm{Cu} K_{\alpha}$ radiation source $(\lambda=0.15405$ $\mathrm{nm}$ ) operated at $40 \mathrm{kV}$ and $40 \mathrm{~mA}$ using a step rate of $0.017^{\circ}$. The morphology of the samples was observed using a scanning electron microscope (SEM, XL30s-FEG, $10 \mathrm{kV}$ ). To determine the true amount of $\mathrm{Ni}$ doped into the $\mathrm{CeO}_{2}$, induced coupled plasma (ICP, Thermo Electron Corporation) analysis was used to test the chemical composition. The Raman spectra of the $\mathrm{Ni}$-containing materials were recorded on a JY HR800 spectrometer at ambient temperature using a laser source of 514 $\mathrm{nm}$ and resolution of $1 \mathrm{~cm}^{-1}$. The X-ray photoelectron spectroscopy (XPS) analysis was performed on a PHI Quantera SXM instrument, using an Al X-ray source, and the binding energies were calibrated using the binding energy of the $\mathrm{C} 1 s(284.8 \mathrm{eV})$ 
peak as a reference. Temperature-programmed reduction (TPR) was performed to determine the reduction behavior of the $5.7 \mathrm{~atm} \% \mathrm{Ni}$-doped and $3.8 \mathrm{~atm} \% \mathrm{Ni}$-loaded catalysts, using $10 \% \mathrm{H}_{2}-90 \% \mathrm{Ar}$ as the reducing gas on a Micromeritics Chem 2920 instrument equipped with a thermal conductivity detector. The samples were heated from room temperature to 900 ${ }^{\circ} \mathrm{C}$ at a rate of $10^{\circ} \mathrm{C} / \mathrm{min}$, and the gas flow rate was $50 \mathrm{ml} / \mathrm{min}$. Typically, $20 \mathrm{mg}$ of fresh catalyst was used in each experiment. A sample pretreatment was performed by flowing Ar over the sample at $300{ }^{\circ} \mathrm{C}$ for $0.5 \mathrm{~h}$, to remove the adsorbed species on the surface. The $\mathrm{H}_{2}$ consumption was determined from the integrated peak area of the reduction profiles.

\subsection{Catalytic testing}

All of the Ni-doped and Ni-loaded samples were examined in the catalysis tests. Activity tests were performed under atmospheric pressure, in a continuous down-flow quartz fixed-bed reactor. The catalyst (50 $\mathrm{mg}$ ) was loaded in the reactor, using quartz wool. A feed with a constant $\mathrm{CO}: \mathrm{O}_{2}: \mathrm{N}_{2}$ volume ratio of 2:3:95 (for $\mathrm{CO}$ oxidation), and $\mathrm{CH}_{4}: \mathrm{O}_{2}: \mathrm{N}_{2}$ volume ratio of
2:1:4 (for POM) was used. The total gas flow rate was 50 $\mathrm{ml} / \mathrm{min}$ for CO oxidation, and $49 \mathrm{ml} / \mathrm{min}$ for POM. The effluent gas was analyzed using an online gas chromatograph (Agilent 7890a) equipped with Porapak Q, ShinCarbon ST, and a thermal conductivity detector (TCD). The conversions of CO and $\mathrm{CH}_{4}$ were calculated as:

$$
\begin{gathered}
X_{\mathrm{CO}}=\mathrm{mol} \mathrm{CO}_{2 \text { out }} /\left(\mathrm{mol} \mathrm{CO}_{\text {out }}+\mathrm{mol} \mathrm{CO} \text { 2out }\right) \times 100 \% \\
X_{\mathrm{CH} 4}=\left(1-\mathrm{mol} \mathrm{CH}_{4 \text { out }} / \mathrm{mol} \mathrm{CH}_{4 \text { in }}\right) \times 100 \%
\end{gathered}
$$

\section{Results and discussion}

\subsection{Characterization results of the catalysts}

All of the Ni-doped ceria catalysts present a peony-like nanostructure morphology, as shown in Fig. 1. Some small particles can be clearly observed on the surface of the Ni-loaded ceria sample. These are suggested to be residual Ni salt. As listed in Table 1, the actual $\mathrm{Ni}$ contents in the samples with nominal compositions of $5,10,15$, and 20 atm\% Ni doping were determined as 1.1, 3.2, 5.7, and 10.7 atm\%, respectively, using ICP analysis. Some of the Ni was lost during the washing
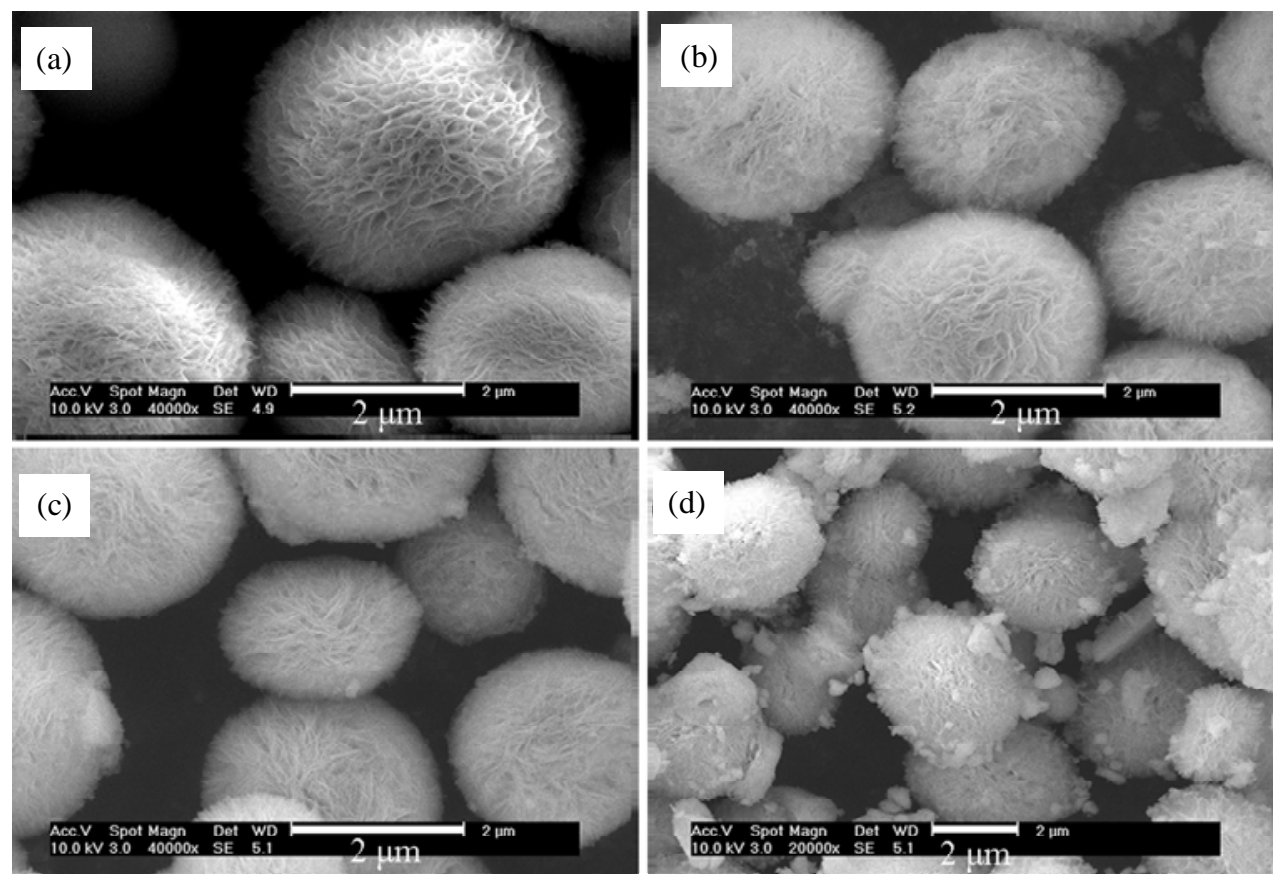

Fig. 1. SEM images of the Ni-doped peony-like $\mathrm{CeO}_{2}$ (PCO) and 3.8 atm\% Ni-loaded PCO catalysts. (a) $1.1 \mathrm{~atm} \%$ Ni doping; (b) 3.2 atm\% Ni doping; (c) $5.7 \mathrm{~atm} \% \mathrm{Ni}$ doping; (d) $3.8 \mathrm{~atm} \%$ Ni loading.

Table 1

\begin{tabular}{|c|c|c|c|c|c|c|c|c|c|c|}
\hline \multicolumn{2}{|c|}{$\mathrm{Ni}$ content (atm\%) } & \multirow{2}{*}{$\mathrm{NiO}$ phase ${ }^{b}$} & \multirow{2}{*}{$\begin{array}{c}\text { Lattice } \\
\text { parameter }^{\mathrm{c}}(\mathrm{nm})\end{array}$} & \multirow{2}{*}{$\begin{array}{l}\mathrm{CeO}_{2} \text { grain } \\
\text { size }^{\mathrm{d}}(\mathrm{nm})\end{array}$} & \multicolumn{2}{|c|}{ Surface element $^{\mathrm{e}}$ (atm\%) } & \multirow{2}{*}{$\begin{array}{c}\text { Surface } \mathrm{Ce} / \mathrm{O} \\
\text { ratio }(\%)\end{array}$} & \multicolumn{3}{|c|}{$\Delta \mathrm{H}_{2}$} \\
\hline Expected $^{\mathrm{a}}$ & ICP result & & & & 0 & $\mathrm{Ni}$ & & P1 & P2 & P3 \\
\hline 0 & - & no & 0.54156 & 6.2 & 77.27 & - & 29.41 & 0 & 0.329 & 0.606 \\
\hline $5^{\mathrm{D}}$ & 1.1 & no & 0.54169 & 6.6 & 79.18 & 0 & 26.30 & - & - & - \\
\hline $10^{\mathrm{D}}$ & 3.2 & no & 0.54171 & 6.8 & 79.18 & 0 & 26.30 & - & - & - \\
\hline $15^{\mathrm{D}}$ & 5.7 & no & 0.54172 & 6.3 & 71.13 & 5.40 & 38.40 & 0.00387 & 0.471 & 0.585 \\
\hline $20^{\mathrm{D}}$ & 10.7 & yes & 0.54157 & 6.5 & - & - & - & - & - & - \\
\hline $5.7^{\mathrm{L}}$ & 3.8 & no & 0.54122 & 10.9 & 75.89 & 13.99 & 31.77 & 0.116 & 0.0678 & 0.571 \\
\hline
\end{tabular}

Characterization results for the Ni-doped/loaded peony-like ceria catalysts.

a The superscript D refers to doping, and L refers to loading. ${ }^{\mathrm{b}}$ From Fig. 2. ${ }^{\mathrm{c}}$ Calculated from the XRD data shown in Fig. 2 using the Jade program.

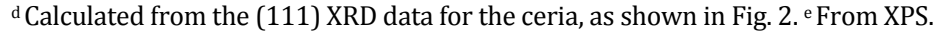




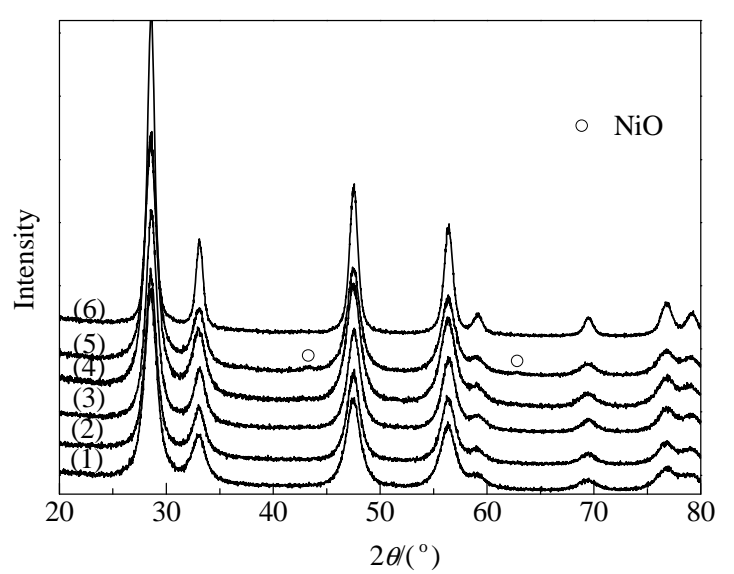

Fig. 2. XRD patterns of different catalyst samples. (1) Pure PCO; (2) 1.1 atm\% Ni-doped PCO; (3) 3.2 atm\% Ni-doped PCO; (4) 5.7 atm\% Ni-doped PCO; (5) 10.7 atm\% Ni-doped PCO; (6) 3.8 atm\% Ni-loaded PCO.

with water and alcohol. Figure 1(d) shows the Ni-loaded PCO catalyst with a nominal composition of $5.7 \mathrm{~atm} \%$. The actual $\mathrm{Ni}$ content was $3.8 \mathrm{~atm} \%$.

The XRD patterns of the samples are shown in Fig. 2. The $\mathrm{NiO}$ phase is not found in the $3.8 \mathrm{~atm} \% \mathrm{Ni}$-loaded PCO catalyst, which could be due to the detection limit of the XRD measurements. It is not clear from these results whether some of the $\mathrm{Ni}$ was doped into the $\mathrm{CeO}_{2}$ lattice, or if it was all dispersed on the surface. This will be clarified in a later section. All of the doped catalysts show a cubic fluorite structure. The NiO phase presents only in the XRD pattern of the $10.7 \mathrm{~atm} \%$ Ni-doped PCO. The lattice parameters of $\mathrm{CeO}_{2}$ increase with increasing of Ni-doping amounts, as listed in Table 1 . The $\mathrm{Ni}^{\mathrm{II}}$ radius $(0.069$ $\mathrm{nm})$ is much smaller than that of $\mathrm{Ce}^{\mathrm{IV}}(0.092 \mathrm{~nm})$, and the lattice should shrink when $\mathrm{Ni}$ enters the $\mathrm{CeO}_{2}$ lattice. In fact, the conversion of $\mathrm{Ce}^{\mathrm{IV}}(0.092 \mathrm{~nm})$ to $\mathrm{Ce}^{\mathrm{III}}(0.103 \mathrm{~nm})$ will happen after the Ni-doping. The increase in the amount of $\mathrm{Ce}^{\mathrm{III}}$ will expand the $\mathrm{CeO}_{2}$ lattice [38], which will counteract the shrinking effects caused by the Ni-doping. The more Ni doping that occurs, the more Ce $\mathrm{CII}$ is generated. Therefore, the $\mathrm{CeO}_{2}$ lattice expands until the shrinking lattice effects of the $\mathrm{Ni}^{\mathrm{II}}$ doping begin to dominate. As shown in Table 1, the lattice parameters of $\mathrm{CeO}_{2}$ decrease to $0.54157 \mathrm{~nm}$ under $10.7 \mathrm{~atm} \%$ of Ni doping. These values are much smaller than those of the other $\mathrm{Ni}$-doped samples. Although it is difficult to determine the real $\mathrm{Ni}$-doping content (due to the appearance of $\mathrm{NiO}$ impurities), it seems that the shrinking effects of the Ni-doping overcome the expanding effects of the increasing Ce ${ }^{\mathrm{III}}$ amounts after 10.7 atm $\%$ of $\mathrm{Ni}$-doping. It should be noted that the lattice parameters for the $3.8 \mathrm{~atm} \% \mathrm{Ni}$-loaded PCO is much smaller than those of pure PCO, as listed in Table 1. After the impregnation process, the $3.8 \mathrm{~atm} \% \mathrm{Ni}$-loaded PCO sample was calcined at 450 ${ }^{\circ} \mathrm{C}$ in air for $4 \mathrm{~h}$, to make the nickel nitrate decompose. Due to extra sintering procedure in air, the amount of Ce $\mathrm{C}^{\mathrm{III}}$ in the bulk material of ceria decreases compared to pure ceria and hence the lattice parameter of ceria decreases in this case [42].

The grain sizes in the prepared catalysts are calculated using the Scherrer equation. The grain size is approximately $6 \mathrm{~nm}$

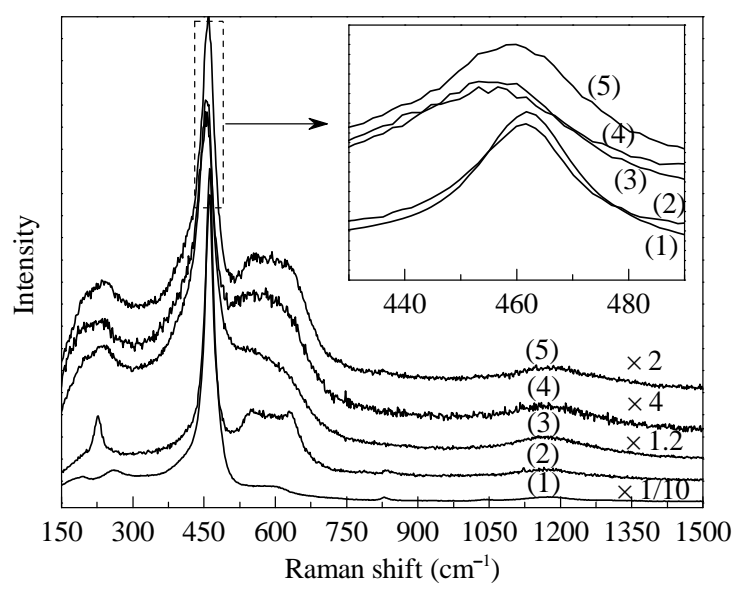

Fig. 3. Raman spectra of different catalyst samples. (1) Pure PCO; (2) 3.8 atm\%Ni-loaded PCO; (3) 1.1 atm\% Ni-doped PCO; (4) 3.2 atm\%Ni-doped PCO; (5) 5.7 atm\%Ni-doped PCO. The small graph inset shows an enlargement of the peak at $450 \mathrm{~cm}^{-1}$.

in all of the Ni-doped samples, but is $10.9 \mathrm{~nm}$ in the $3.8 \mathrm{~atm} \%$ Ni loaded PCO, as shown in Table 1. After the impregnation process, the $3.8 \mathrm{~atm} \% \mathrm{Ni}$-loaded PCO sample was calcined at $450{ }^{\circ} \mathrm{C}$ for $4 \mathrm{~h}$ in air to make the nickel nitrate decompose. This extra sintering also made the PCO grains grow bigger compared with those in the doped samples, which did not occur extra sintering.

The Raman spectra are shown in Fig. 3. The peak at 462.0 $\mathrm{cm}^{-1}$, the typical $\mathrm{F}_{2 \mathrm{~g}}$ Raman active modes of a fluorite structured ceria [43], shift to $455.2,455.0$, and $459.8 \mathrm{~cm}^{-1}$ for the $1.1,3.2$, and $5.7 \mathrm{~atm} \% \mathrm{Ni}$-doped samples, respectively. It does not shift for the Ni-loaded sample. For clarity, an enlargement of the spectra is shown in the inset. The red-shift suggests a significant modification of the M-O bonding symmetry, which probably results from the presence of $\mathrm{Ni}$ in the fluorite lattice $[40,44]$. As mentioned above, the doping of $\mathrm{Ni}$ into the ceria lattice results in extra strain and increases the concentration of Ce ${ }^{\text {III }}$ in the bulk [38], which also influences the Raman bands. The shoulder peaks around 230 and $590 \mathrm{~cm}^{-1}$ are related to the addition of $\mathrm{Ni}$. The relative intensity of the band from 540 to $636 \mathrm{~cm}^{-1}$ increases with increases in the Ni-doping amount. This is ascribed to the formation of oxygen vacancies in the Ni-doped ceria [45].

The XPS spectra for the binding energies of Ce $3 d$ and Ni $2 p$ core levels are given in Fig. 4. The signals from $\mathrm{Ce}^{\mathrm{IV}}$ are marked as $\mathrm{u}, \mathrm{u}$ ", and $\mathrm{u}^{\prime \prime}$ for $3 d_{3 / 2}$, while those for $3 d_{5 / 2}$ are marked as $\mathrm{v}$, $v^{\prime \prime}$, and $v^{\prime \prime}$. The four peaks labeled as $u^{0}, u^{\prime}, v^{0}$, and $v^{\prime}$ were assigned to Ce ${ }^{\mathrm{III}}$, as reported in the literature [46]. Although the absolute binding energies are referenced against the $\mathrm{C} 1 \mathrm{~s}$ photoelectron peak at $284.8 \mathrm{eV}$, some scattering of the binding energies in the Ce $3 d$ and $\mathrm{Ni} 2 p$ regions could occur. This is due to the low conductivity of the catalysts, which caused charging effects. Therefore, the positions of the peaks may not have reflected the exact binding energies. However, it is clear from Fig. 4 (a) that the relative intensities of the $v^{0} / v, v^{\prime}, u^{0} / u$, and $u^{\prime}$ peaks increase with increasing amounts of doped Ni. This behavior was not observed in the Ni-loaded catalyst. The $\mathrm{u}^{0} / \mathrm{u}$ and $\mathrm{v}^{0} / \mathrm{v}$ peaks are too close to be distinguished, but from the in- 

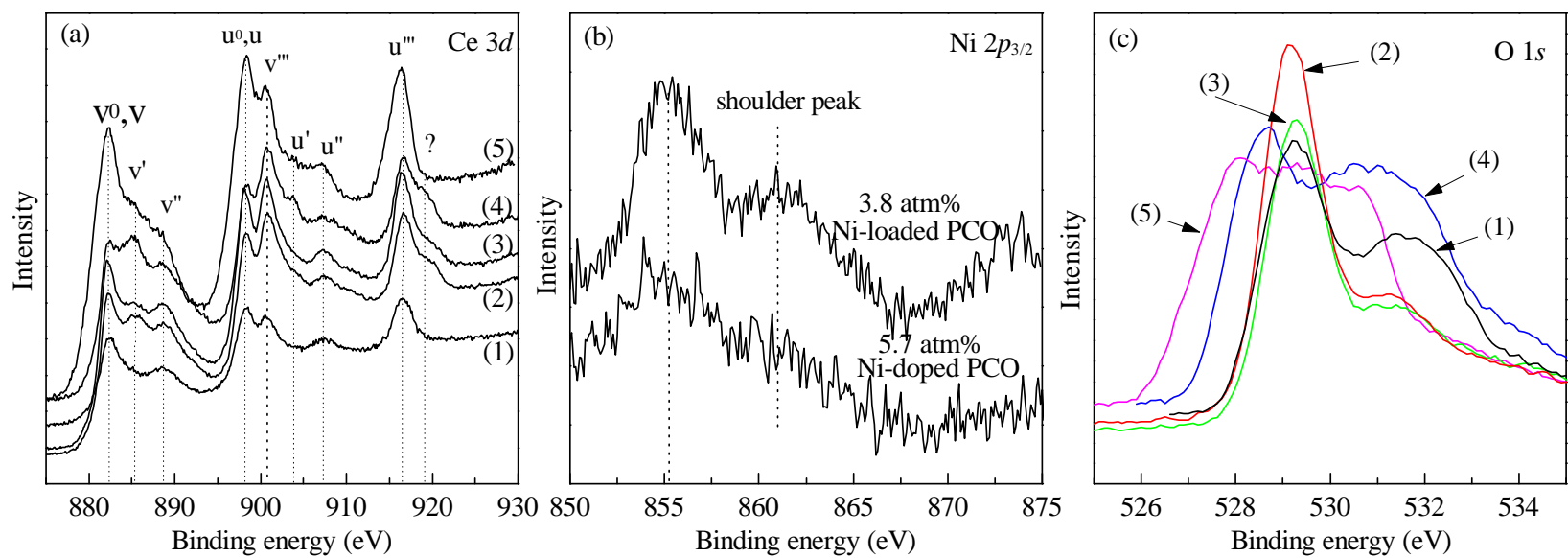

Fig. 4. Ce $3 d$ (a), Ni $2 p$ (b), and $01 s$ (c) XPS spectra of the samples. (1) Pure PCO; (2) 1.1 atm\% Ni-doped PCO; (3) 3.2 atm\% Ni-doped PCO; (4) 5.7 atm\% Ni-doped PCO; (5) 3.8 atm\% Ni-loaded PCO. Ce ${ }^{\text {IV }}$ peaks are marked as u, u", and u'" for $3 d_{3 / 2}$ and v, v", and v"' for $3 d_{5 / 2}$. The four peaks labeled as $\mathrm{u}^{0}, \mathrm{u}^{\prime}, \mathrm{v}^{0}$, and $\mathrm{v}^{\prime}$ were assigned to Ce $\mathrm{e}^{\mathrm{III}}$.

crease of the relative intensity of the $v^{\prime}$ and $u^{\prime \prime}$ peaks, it is clear that the Ce $\mathrm{C}^{\mathrm{III}}$ concentration increases with increasing $\mathrm{Ni}$-doping amounts. A similar phenomenon has been reported for $\mathrm{Cu}$ and Zr-doped ceria materials $[47,48]$.

Compared with pure ceria, the $v^{\prime}$ and $u^{\prime}$ peak intensities for the 3.8 atm\% Ni-loaded PCO show insignificant change compared with those of the $5.7 \mathrm{~atm} \% \mathrm{Ni}$-doped catalyst, which is in accordance with the Raman spectra results. The Ni contents on the catalyst surface (as detected by XPS) are listed in Table 1. There is no obvious Ni signal from the surfaces of the $1.1 \mathrm{~atm} \%$ Ni-doped or $3.2 \mathrm{~atm} \% \mathrm{Ni-doped} \mathrm{catalysts,} \mathrm{and} \mathrm{the} \mathrm{surface} \mathrm{nick-}$ el content is $5.4 \mathrm{~atm} \%$ for the $5.7 \mathrm{~atm} \%$ Ni-doped sample, which is similar to the bulk nickel content. In contrast, the surface nickel content is $13.44 \mathrm{~atm} \%$ for the Ni-loaded catalyst, which is three times higher than the actual composition of 3.8 atm\%. This is consistent with the fact that the Ni particles are mostly dispersed on the surface of the $3.8 \mathrm{~atm} \%$ Ni-loaded PCO sample. In addition, it is found that the peak at approximately $919.4 \mathrm{eV}$ in the Ce $3 d$ core level grows larger with increases in the doped $\mathrm{Ni}$ amount. This is clearly related to the nickel-doping behavior, and the same peak is not observed in the spectra of the $3.8 \mathrm{~atm} \% \mathrm{Ni}$-loaded PCO. The Ni $2 p$ spectra of the 5.7 atm\% Ni-doped and 3.8 atm\% Ni-loaded PCOs are compared in Fig. 4(b). In the Ni-loaded catalyst, there are two distinct peaks at $\sim 855.3$ and $\sim 861 \mathrm{eV}$, which were assigned to $\mathrm{Ni}^{\mathrm{II}}$. The peak at approximately $861 \mathrm{eV}$ does not present, and the peak at approximately $855.3 \mathrm{eV}$ broadens. This indicates the different chemical environments surrounding the $\mathrm{Ni}$ in the loaded and doped catalysts.

The $01 s$ spectra of the samples are shown in Fig. 4(c). There are two peaks in the pure PCO and Ni-doped PCO samples and three peaks in the Ni-loaded PCO sample. The $01 s$ peaks at 529.25 and $531.75 \mathrm{eV}$ in PCO, which are assigned to the ceria-related lattice oxygen, and the adsorbed oxygen species on the surface, respectively [49,50], shifted to 529.20 and 531.30 $\mathrm{eV}$ after $1.1 \mathrm{~atm} \% \mathrm{Ni}$ and $3.2 \mathrm{~atm} \% \mathrm{Ni}$ doping, and to 528.65 and $530.95 \mathrm{eV}$ after $5.7 \mathrm{~atm} \% \mathrm{Ni}$ doping. The $01 \mathrm{~s}$ peaks at $528.10,529.25$, and $530.60 \mathrm{eV}$ in the $3.8 \mathrm{~atm} \%$ Ni-loaded samples and the new peak at $528.10 \mathrm{eV}$ that was related to $\mathrm{O}^{2-}$ were also found in $\mathrm{LaNiO}_{3}$ [51]. The surface 0 contents are listed in Table 1. They slightly increase from $77.27 \%$ to $79.18 \%$ after $1.1 \mathrm{~atm} \% \mathrm{Ni}$ or $3.2 \mathrm{~atm} \% \mathrm{Ni}$ doping, but rapidly reduce to $71.13 \%$ and $67.99 \%$ after $5.7 \mathrm{~atm} \% \mathrm{Ni}$ doping and $3.8 \mathrm{~atm} \% \mathrm{Ni}$ loading, respectively. The surface 0 content is closely related to the reduction of surface ceria [49]. According to the changes in the ratio of Ce to 0 on the surface, as listed in Table 1 , it is clearly that the Ni loading and doping reduce the surface oxygen content. That is, they enhance the oxygen vacancy content on the surface. However, it is found that the $\mathrm{Ce} / \mathrm{O}$ ratio in the $1.1 \mathrm{~atm} \% \mathrm{Ni}$ doping and $3.2 \mathrm{~atm} \% \mathrm{Ni}$ doping samples is a little lower than that in PCO. In these two samples, the doped nickel was not be detected using XPS. However, it is likely that the nickel combines with the oxygen on the surface, which contributes to the slightly lower Ce/O ratio of $26.30 \%$ in the $1.1 \mathrm{~atm} \%$ $\mathrm{Ni}$ doping and $3.2 \mathrm{~atm} \% \mathrm{Ni}$ doping samples, compared with of the value of $29.41 \%$ found for PCO. It is found that there are more oxygen vacancies on the surface of the $5.7 \mathrm{~atm} \% \mathrm{Ni}$ doped sample compared with the $3.8 \mathrm{~atm} \% \mathrm{Ni}$-loaded sample.

According to the XRD, Raman spectroscopy, and XPS results given here, the lattice shrinking of $\mathrm{CeO}_{2}$ is induced after $\mathrm{Ni}$ doping. To suppress the structure deformation, more Ce $\mathrm{CIII}^{\mathrm{III}}$ generated, since its ionic radius is larger than that of $\mathrm{Ce}^{\mathrm{IV}}$. This can explain the increases in the Ce $\mathrm{e}^{\mathrm{III}}$ concentration after $\mathrm{Ni}$ doping. According to the above results, the defect chemistry could be written in Kröger-Vink notation as follows:

$$
2 \mathrm{NiO}+\mathrm{CeO}_{2}=\mathrm{Ni}_{\text {celv" }}{ }^{\prime}+2 \mathrm{~V}_{\mathrm{O}}{ }^{\cdots}+\mathrm{Ce}_{\text {Celv' }}+\mathrm{Ni}_{\text {celII' }}+2 \mathrm{O}_{2}
$$

\subsection{TPR results}

The $5.7 \mathrm{~atm} \%$ Ni-doped PCO sample and the $3.8 \mathrm{~atm} \%$ Ni-loaded PCO sample were selected to compare the influence of Ni doping and loading on the reduction properties of PCO. The TPR spectra are shown in Fig. 5 and the results are summarized in Table 1. Two peaks are identified. The peak at 380 ${ }^{\circ} \mathrm{C}$ (marked as P2) is attributed to the surface reduction of the ceria, and the second peak at $655{ }^{\circ} \mathrm{C}$ (marked as P3) is related to the bulk reduction of the ceria. The reduction temperatures are much lower than the reported temperatures of $\sim 500$ and 


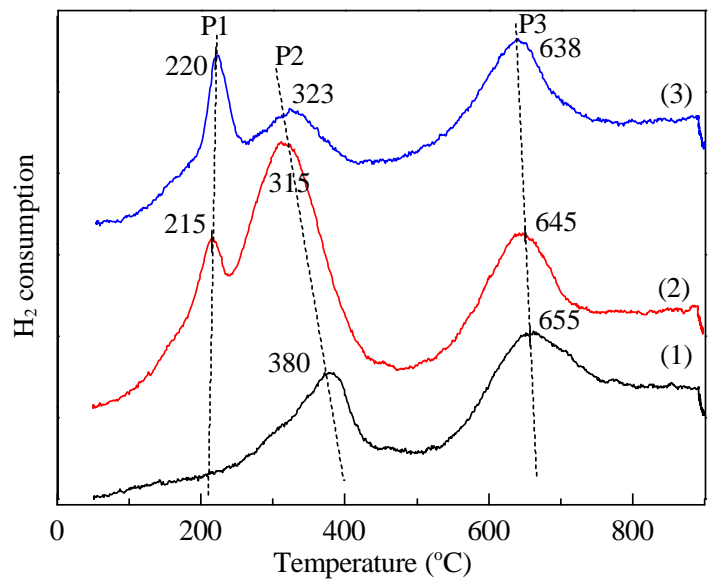

Fig. 5. TPR profiles for the selected samples. (1) Pure PCO; (2) 5.7 atm\% Ni-doped PCO; (3) 3.8 atm\% Ni-loaded PCO.

$\sim 800{ }^{\circ} \mathrm{C}[9,48]$. When $\mathrm{Ni}$ is introduced, regardless of the doping or loading, the P2 and P3 shift to lower temperature. This shows that the presence of Ni promotes the reduction of ceria. In addition, the $\mathrm{P} 1$ below $300{ }^{\circ} \mathrm{C}$ in the spectra of the $\mathrm{Ni}$-containing samples was assigned to the reduction of $\mathrm{Ni}$ [52]. For the $5.7 \mathrm{~atm} \% \mathrm{Ni}$-doped PCO, the P1 may be related to the reduction of $\mathrm{Ni}$ in the ceria close to the surface. The $\mathrm{P} 2$ for the $\mathrm{Ni}$-doped sample is at $315{ }^{\circ} \mathrm{C}$, much lower than that for PCO, which is at $380{ }^{\circ} \mathrm{C}$. The $\mathrm{P} 2$ peak consumes much more $\mathrm{H}_{2}$ for reduction on the Ni doped PCO catalyst than that on PCO. This indicates that the Ni doping promotes the reduction of the ceria surface. The P2 for the $3.8 \mathrm{~atm} \%$ Ni-loaded PCO decreases to $323{ }^{\circ} \mathrm{C}$, indicating that interactions occur between the loaded $\mathrm{Ni}$ and the surface of the ceria. However, the $\mathrm{H}_{2}$ consumption of the $3.8 \mathrm{~atm} \% \mathrm{Ni-loaded} \mathrm{PCO} \mathrm{is} \mathrm{lower} \mathrm{than} \mathrm{that} \mathrm{of} \mathrm{PCO.} \mathrm{This} \mathrm{is}$ probably because the dispersion of $\mathrm{Ni}$ particles on the surface partly blocks the reduction of the ceria. The P3 associated with the reduction of the bulk ceria does not shift significantly for either the $5.7 \mathrm{~atm} \%$ Ni-doped sample or the $3.8 \mathrm{~atm} \%$ $\mathrm{Ni}$-loaded sample, and the P3 peak area for the three samples is similar, which shows that the Ni loading and doping have no significant influence on the reduction of bulk ceria. Comparing the relative intensity of $\mathrm{P} 1$ to that of $\mathrm{P} 2$ and $\mathrm{P} 3$, it is quite clear that the amount of reducible $\mathrm{Ni}$ is higher in the $3.8 \mathrm{~atm} \%$ Ni-loaded PCO sample than in the 5.7 atm\% Ni-doped PCO. This is consistent with the XPS results showing that $\mathrm{Ni}$ is distributed uniformly within the lattice of the Ni-doped sample.

\subsection{Catalytic activity}

The CO oxidation results are shown in Fig. 6. All of the $\mathrm{Ni}$-containing catalysts show higher activities compared to the pristine PCO. It is clear that this improvement effect is not related to changes in the specific surface area of the catalyst since the specific surface area of the pure PCO is above $100 \mathrm{~m}^{2} / \mathrm{g}$ $[14,15]$, and is not significantly changed after small amounts of $\mathrm{Ni}$ loading or doping. The catalytic activity of the Ni-doped catalyst increases with the increasing of the $\mathrm{Ni}$ doping amount. The activity of the $3.8 \mathrm{~atm} \%$ Ni-loaded PCO is lower than that of

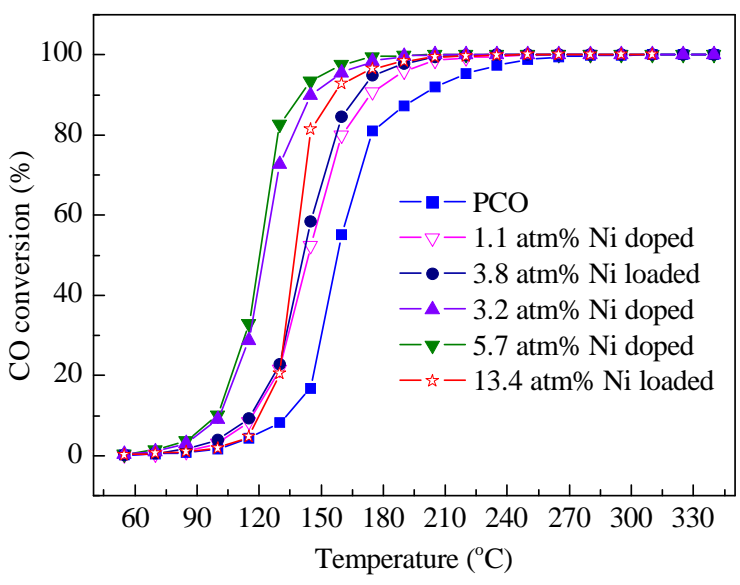

Fig. 6. CO conversion for all Ni-doped and Ni-loaded PCO catalysts. The catalyst (50 mg) was loaded in the reactor using quartz wool. A feed with a constant $\mathrm{CO}: \mathrm{O}_{2}: \mathrm{N}_{2}$ volume ratio of $2: 3: 95$ was used. The total gas flow rate was $50 \mathrm{ml} / \mathrm{min}$.

$3.2 \mathrm{~atm} \%$ Ni-doped PCO. To further clarify why the effects of the Ni doping is superior to those of the Ni loading, a sample of 13.4 atm\% Ni-loaded PCO (actual composition) was also prepared using the impregnation method, and was tested for CO oxidation. The activity of the $13.4 \mathrm{~atm} \% \mathrm{Ni}$-loaded PCO is also lower than the activity of the $3.2 \mathrm{~atm} \% \mathrm{Ni}$-doped PCO and the 5.7 atm\% Ni-doped PCO. Therefore, the Ni doping is more effective in enhancing the activity than the Ni-loading. It has been reported that the releasable lattice oxygen on the ceria surface could be the key reactant for the oxidation of the adsorbed CO [12,53-56]. As shown in the TPR profiles in Fig. 5, the 3.8 atm $\%$ Ni-loaded PCO has more reducible Ni, but less reducible surface ceria than the $5.7 \mathrm{~atm} \%$ Ni-doped PCO sample. This result supports the findings from previous investigations that the surface reducibility of $\mathrm{CeO}_{2}$ is an essential factor for $\mathrm{CO}$ oxidation, at least for ceria-based catalysts [12,53-56].

Data for the partial oxidation of methane is shown in Fig. 7. The $\mathrm{CH}_{4}$ conversion ratio of the Ni-doped catalysts increases with the increasing of the doped Ni amount. The activity of PCO

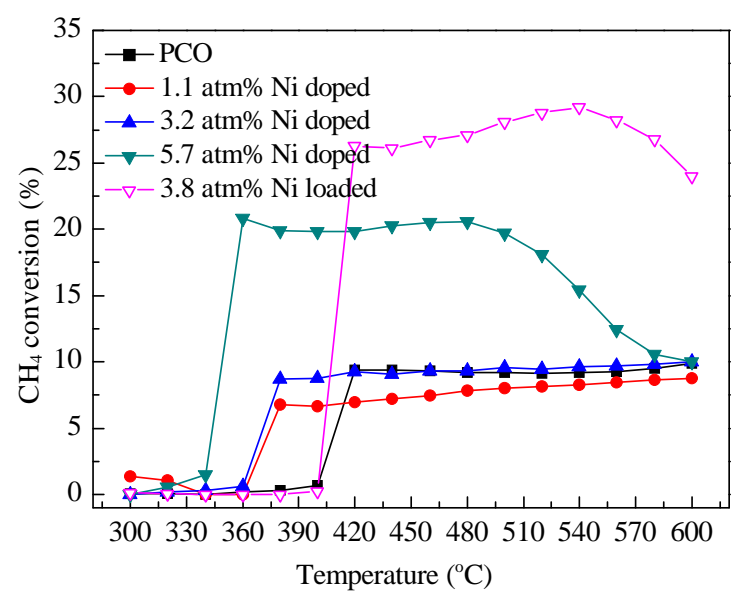

Fig. 7. Partial oxidation of $\mathrm{CH}_{4}$ on catalysts. The catalyst $(50 \mathrm{mg})$ was loaded in the reactor, using quartz wool. A feed with a constant $\mathrm{CH}_{4}: \mathrm{O}_{2}: \mathrm{N}_{2}$ volume ratio of $2: 1: 4$ was used. The total gas flow rate was 49 $\mathrm{ml} / \mathrm{min}$. 
is similar to that of the $3.2 \mathrm{~atm} \% \mathrm{Ni}$-doped PCO for the temperature range tested, and is slightly higher than the activity shown by the $1.1 \mathrm{~atm} \% \mathrm{Ni}$-doped PCO sample. The $5.7 \mathrm{~atm} \%$ Ni-doped PCO shows a $20 \%$ conversion ratio at $350{ }^{\circ} \mathrm{C}$. Compared with the Ni-doped PCO catalysts, the $3.8 \mathrm{~atm} \%$ Ni-loaded PCO sample shows a much higher conversion ratio of $28 \%$ at $540{ }^{\circ} \mathrm{C}$, which is also higher than the ratios shown by all of the doped and un-doped PCO samples. Ni metal sites are known for methane activation [10,57], and our results indicate that the reducible Ni plays an important role in the POM reaction. The methane conversion ratio begins to decrease at $480{ }^{\circ} \mathrm{C}$ and 540 ${ }^{\circ} \mathrm{C}$ on $5.7 \mathrm{~atm} \%$ Ni-doped PCO and $3.8 \mathrm{~atm} \%$ Ni-loaded PCO catalyst respectively. This is attributed to the degradation of the catalysts after the reaction, which likely occurs because of carbon formation and the coarsening of the PCO grain growth. This was confirmed by the XRD measurements performed after the POM tests (data not shown).

It is interesting to note that for the PCO-based catalysts, the onset temperature for $\mathrm{CH}_{4}$ conversion is strongly influenced by the Ni doping. The reforming reaction starts at $400{ }^{\circ} \mathrm{C}$ for the PCO and the Ni-loaded PCO samples. It decreases to 360, 360, and $340{ }^{\circ} \mathrm{C}$ for the $1.1,3.2$, and $5.7 \mathrm{~atm} \% \mathrm{Ni}$-doped PCO samples, respectively. These onset temperatures are much lower than those reported previously for Ni-loaded ceria catalysts, or catalysts with other supports [9,57-60]. The decreasing trend for the onset temperature in the POM reaction could be related to the oxygen vacancy generation, or the enhancement in the reduction of surface ceria, caused by the Ni doping. Due to the complicated reaction mechanism of POM, a clear understanding of this process will require further investigations.

\section{Conclusions}

Hierarchically nanostructured Ni-doped and Ni-loaded peony-like ceria materials have been successfully prepared, and show high activity for $\mathrm{CO}$ oxidation and the partial oxidation of methane. Ni doping is favorable for the formation of Ce $\mathrm{Ce}^{\mathrm{III}}$ in ceria, and enhances the reduction of surface ceria. The $\mathrm{Ni}$-doped samples therefore show much higher activity for $\mathrm{CO}$ oxidation than the Ni-loaded samples. It is believed that the surface oxygen vacancy induced by Ni doping is essential for $\mathrm{CO}$ oxidation. The onset temperature for $\mathrm{CH}_{4}$ conversion is highly dependent on the $\mathrm{Ni}$ doping amount. It decreases from $400{ }^{\circ} \mathrm{C}$ for the pure PCO and the $3.8 \mathrm{~atm} \%$ Ni-loaded PCO sample, to $340{ }^{\circ} \mathrm{C}$ for the $5.7 \mathrm{~atm} \% \mathrm{Ni}$-doped PCO sample. The $3.8 \mathrm{~atm} \%$ Ni-loaded PCO sample realizes the highest $\mathrm{CH}_{4}$ conversion ratio of $28 \%$ at $540{ }^{\circ} \mathrm{C}$. It is thought that the exposed reducible $\mathrm{Ni}$ is more important for the partial oxidation of methane than the ceria surface or the doped Ni. The Ni-doped PCO samples show interesting effects for the oxidation of $\mathrm{CO}$ and the partial oxidation of methane, which should be useful for the design of catalysts and the understanding of catalytic mechanisms.

\section{Acknowledgments}

Dr. Xia Lu is thanked for the helpful discussions. Dr. K. Y. Cheung's assistance on editing the manuscript is appreciated.

\section{References}

[1] Liu W W, Zhou K B, Wang L, Wang B Y, Li Y D. J Am Chem Soc, 2009, 131: 3140

[2] Sun C W, Li H, Chen L Q. J Phys Chem Solids, 2007, 68: 1785

[3] Shan W J, Liu Ch, Guo H J, Yang L H, Wang X N, Feng Zh Ch. Chin J Catal (单文娟, 刘畅, 郭红娟, 杨利华, 王晓楠, 冯兆池. 催化学 报), 2011, 32: 1336

[4] Carrettin S, Concepcion P, Corma A, Nieto J M L, Puntes V F. Angew Chem, Int Ed, 2004, 43: 2538

[5] Li Y, Fu Q, Flytzani-Stephanopoulos M. Appl Catal B, 2000, 27: 179

[6] Rim K T, Eom D, Liu L, Stolyarova E, Raitano J M, Chan S W, Flytzani-Stephanopoulos M, Flynn G W. J Phys Chem C, 2009, 113: 10198

[7] Wang K, Li X J, Ji S F, Shi X J, Tang J J. Energy Fuels, 2009, 23: 25

[8] Laosiripojana N, Assabumrungrat S. Appl Catal B, 2006, 66: 29

[9] Trovarelli A. Catal Rev Sci Eng, 1996, 38: 439

[10] Huang T J, Wang C H. Chem Eng J, 2007, 132: 97

[11] Huang T J, Yu T C. Catal Lett, 2005, 102: 175

[12] Xiao G L, Li S, Li H, Chen L Q. Microporous Mesoporous Mater, 2009, 120: 426

[13] Yuan Q, Duan H H, Li L L, Li Z X, Duan W T, Zhang L S, Song W G, Yan C H. Adv Mater, 2010, 22: 1475

[14] Sun C W, Sun J, Xiao G L, Zhang H R, Qiu X P, Li H, Chen L Q.J Phys Chem B, 2006, 110: 13445

[15] Sun C W, Li H, Chen L Q. Energy Environ Sci, 2012, 5: 8475

[16] Xian C N, Li H, Chen L Q, Lee J S. Microporous Mesoporous Mater, 2011, 142: 202

[17] Sun J, Wang Y G, Li J G, Xiao G L, Zhang L G, Li H, Cheng Y L, Sun C W, Cheng Z X, Dong Z C, Chen L Q. Int J Hydrogen Energy, 2010, 35 : 3087

[18] Sun C W, Xie Z, Xia C R, Li H, Chen L Q. Electrochem Commun, 2006, 8: 833

[19] Xiao G, Jiang Z, Li H, Xia C, Chen L Q. Fuel Cells, 2009, 9: 650

[20] Konyshev E, Blackley R, Irvine J T S. Chem Mater, 2010, 22: 4700

[21] York A P E, Xiao T C, Green M L H. Top Catal, 2003, 22: 345

[22] Tomishige K. JJpn Pet Inst, 2007, 50: 287

[23] Ni M, Leung D Y C, Leung M K H. Int J Hydrogen Energy, 2007, 32: 3238

[24] Kugai J, Velu S, Song C S. Catal Lett, 2005, 101: 255

[25] Rasko J, Hancz A, Erdohelyi A. Appl Catal A, 2004, 269: 13

[26] Bradford M C J, Vannice M A. Appl Catal A, 1996, 142: 73

[27] Biswas P, Kunzru D. Catal Lett, 2007, 118: 36

[28] Huang T J, Huang M C, Huang M S. Appl Catal A, 2009, 354: 127

[29] Sayle T X, Parker S C, Catlow S C C. Surf Sci, 1994, 316: 329

[30] Zhu T L, Flytzani-Stephanopoulos M. Appl Catal A, 2001, 208: 403

[31] Kumar P, Sun Y P, Idem R O. Energy Fuels, 2008, 22: 3575

[32] Daza C E, Kiennemann A, Moreno S, Molina R. Appl Catal A, 2009, 364: 65

[33] Aupretre F, Descorme C, Duprez D. Catal Commun, 2002, 3: 263

[34] Moon D J. Catal Surv Asia, 2008, 12: 188

[35] Choudary V R, Rajput A M, Prabhakar B. J Catal, 1993, 139: 326

[36] Noronha F B, Fendley E C, Soares R R, Alvarez W E, Resasco D E. Chem Eng J, 2001, 82: 21

[37] Wang X Q Rodriguez J A, Hanson J C, Gamarra D, Martinez-Arias A, Fernandez-Garcia M. J Phys Chem B, 2005, 109: 19595

[38] Thurber A, Reddy K M, Shutthanandan V, Engelhard M H, Wang C, Hays J, Punnoose A. Phys Rev B, 2007, 76: 165206-1

[39] Jalowiecki-Duhamel L, Ponchel A, Lamonier C. Int J Hydrogen Energy, 1999, 24: 1083

[40] Yisup N, Cao Y, Feng W L, Dai W L, Fan K N. Catal Lett, 2005, 99 : 207

[41] Kaneko H, Tamaura Y. J Phys Chem Solids, 2009, 70: 1008 


\section{Graphical Abstract}

Chin. J. Catal., 2013, 34: 305-312 doi: 10.1016/S1872-2067(11)60466-X

Effect of Ni doping on the catalytic properties of nanostructured peony-like $\mathrm{CeO}_{2}$

XIAN Cunni, WANG Shaofei, SUN Chunwen, LI Hong*, CHAN Suiwai, CHEN Liquan Institute of Physics, Chinese Academy of Sciences, China; Columbia University, USA
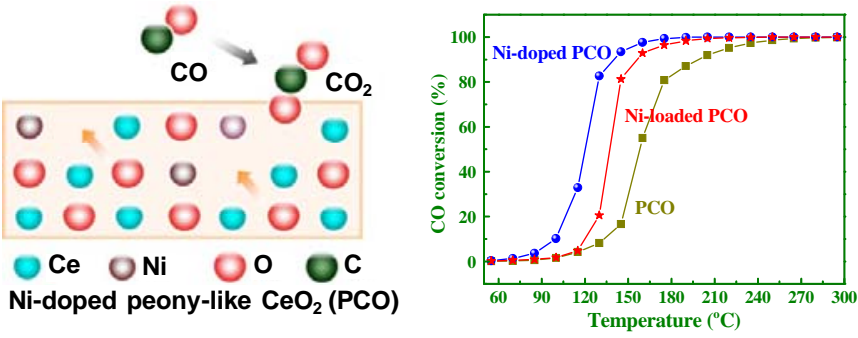

Oxygen vacancies are generated in bulk ceria after Ni doping, which promotes the reducibility of peony-like $\mathrm{CeO}_{2}$, and hence enhances the catalytic activity for CO oxidation.

[42] Mogensen M, Sammes N M, Tompsett G A. Solid State Ionics, 2000, 129: 63

[43] Thammachart M, Meeyoo V, Risksomboon T, Osuwan S. Catal Today, 2001, 68: 53

[44] Barrio L, Kubacka A, Zhou G, Estrella M, Martinez-Arias A, Hanson J C, Fernandez-Garcia M, Rodriguez J A. J Phys Chem C, 2010, 114: 12689

[45] McBride J R, Hass K C, Poindexter B D, Weber W H. J Appl Phys, 1994, 76: 2435

[46] Larese C, Granados M L, Mariscal R, Fierro J L G, Lambrou P S, Efstathiou A M. Appl Catal B, 2005, 59: 13

[47] Hocevar S, Batista J, Levec J.J Catal, 1999, 184: 39

[48] Zhang F, Chen C H, Raitano J M, Hanson J C, Caliebe W A, Khalid S, Chan S W. J Appl Phys, 2006, 99: 084313

[49] Yu Q Q, Li Y, Zou X H, Zhuo H Y, Yao Y Y, Suo Zh H. Chin J Catal (于 强强, 李杨, 邹旭华, 卓红英, 姚媛媛, 索掌怀. 催化学报), 2010, 31: 671
[50] Reddy B M, Bharali P, Saikia P, Park S E, van den Berg M W E, Muhler M, Grunert W.J Phys Chem C, 2008, 112: 11729

[51] Choisnet J, Klissurski D, Abadzhieva N, Stefanov P, Minchev L. J Chem Soc, Faraday Trans, 1994, 90: 1987

[52] Ivanova A S. Kinet Catal, 2009, 50: 797

[53] Liu W, Flytzani-Stephanopoulos M. Chem Eng J, 1996, 64: 283

[54] Ramesh K, Chen L W, Chen F X, Liu Y, Wang Z, Han Y F. Catal Today, 2008, 131: 477

[55] Cracium R, Nentwick B, Hadjiivanov K, Köninger H. Appl Catal A, 2003, 243: 67

[56] Molina L M, Hammer B. Phys Rev B, 2004, 69: 155424-1

[57] Kundakovic L, Flytzani-Stephanopoulos M. J Catal, 1998, 179: 203

[58] Choudhary V R, Rajput A M, Mamman A S. J Catal, 1998, 178: 576

[59] Zhu T L, Flytzani-Stephanopoulos M. Appl Catal A, 2001, 208: 4037

[60] Silva F A, Ruiz J A C, de Souza K, Bueno J M C, Mattos L V, Noronha F B, Hori C E. Appl Catal A, 2009, 364: 122

\section{$\mathrm{Ni}$ 掺杂对纳米结构牡丹花状 $\mathrm{CeO}_{2}$ 材料催化特性的影响 \\ 仙存妮 ${ }^{\mathrm{a}}$, 王少飞 ${ }^{\mathrm{a}}$, 孙春文 ${ }^{\mathrm{a}}$, 李 泓 ${ }^{\mathrm{a},{ }^{*}}$, 陈晓惠 ${ }^{\mathrm{b}}$, 陈立泉 ${ }^{\mathrm{a}}$ \\ a中国科学院物理研究所清洁能源重点实验室, 北京 100190 \\ $\mathrm{b}^{\mathrm{G}}$ 伦比亚大学应用物理与应用数学学院, 美国纽约}

摘要: 制备了一种新型 $\mathrm{Ni}$ 掺杂多层纳米结构告丹花状 $\mathrm{CeO}_{2}$ 材料, 研究了其催化性能, 同时与 $\mathrm{Ni}$ 负载牡丹花状 $\mathrm{CeO}_{2}$ 样品进行了比 较. 结果表明, $\mathrm{Ni}$ 掺杂 $\mathrm{CeO}_{2}$ 样品具有纳米晶粒和开放的介孔结构,特殊的形貌使其在 $\mathrm{CO}$ 氧化和甲烷部分氧化反应中具有独特的 催化特性. $\mathrm{Ni}$ 掺杂后, $\mathrm{CeO}_{2}$ 中产生了多余氧空位, 同时其氧化还原活性也增强, 其在 $\mathrm{CO}$ 氧化反应中的催化活性明显高于纯 $\mathrm{CeO}_{2}$ 和 $\mathrm{Ni}$ 负载 $\mathrm{CeO}_{2}$ 样品; 在甲烷部分氧化反应中, 告丹花状 $\mathrm{CeO}_{2}$ 负载 $3 \mathrm{~atm} \% \mathrm{Ni}$ 催化剂样品上甲烷转化率高于所有 $\mathrm{Ni}$ 掺杂的催化剂样 品. 但是在 $\mathrm{Ni}$ 负载型催化剂和花状 $\mathrm{CeO}_{2}$ 催化剂上, 甲烷的起始转化温度为 $400^{\circ} \mathrm{C}$, 而 $5.7 \mathrm{~atm} \% \mathrm{Ni}$ 的掺杂使其降至 $340^{\circ} \mathrm{C}$.

关键词: 纳米结构氧化铈; 镍; 一氧化碳; 氧化; 甲烷; 部分氧化

收稿日期: 2012-08-13. 接受日期: 2012-10-12. 出版日期: 2013-02-20.

*通讯联系人. 电话: (010)82649047; 传真: (010)82649046; 电子信箱: hli@iphy.ac.cn 基金来源: 国家自然科学基金 (511172275); 国家重点基础研究发展计划 (973 计划, 2012CB215402).

本文的英文电子版由Elsevier出版社在ScienceDirect上出版(http://www.sciencedirect.com/science/journal/18722067). 